\title{
The relationship between fishing characteristics of Pacific bluefin tuna (Thunnus orientalis) and ocean conditions around Jeju Island
}

\author{
Ari Shin ${ }^{1}$, Sang Chul Yoon ${ }^{1}$, Sung II Lee ${ }^{1 *}$, Hee Won Park ${ }^{1}$ and Suam Kim²
}

\begin{abstract}
Pacific bluefin tuna (Thunnus orientalis) is one of the commercially important species in Korea as well as other countries of the North Pacific. Korean offshore large purse seine fisheries targeting small pelagic fishes such as chub mackerel have caught T. orientalis temporarily in the east of Jeju Island. The catch of T. orientalis in March through June occupied approximately 60\% of the total. The monthly catch around Jeju Island from 2004 to 2013 showed a negative correlation $(r=-0.755, p<0.01)$ with the seawater temperature at $50 \mathrm{~m}$ and had a significant positive correlation $(r=0.856, p<0.01)$ with the Pacific Decadal Oscillation Index (PDOI). The highest catch and catch per unit effort (CPUE) of T. orientalis around Jeju Island occurred either when the seawater temperature ranged between 15 and $16^{\circ} \mathrm{C}$ at $50 \mathrm{~m}$ or when the catch was taken near the frontal area where two water masses from offshore and coastal areas collide. The length of T. orientalis caught around Jeju Island from 2004 to 2013 ranged from 19 to $193 \mathrm{~cm}$ in fork length (FL). The time series of the monthly mean FL of $T$. orientalis had a negative correlation $(r=-0.592, p<0.01)$ with the seawater temperature at $50 \mathrm{~m}$ and had a significant positive correlation $(r=0.668, p<0.05)$ with PDOI.
\end{abstract}

Keywords: Thunnus orientalis, Fishing ground, Environmental factors, Seawater temperature, Pacific Decadal Oscillation Index (PDOI)

\section{Background}

There are three species of bluefin tuna in the world: Pacific bluefin tuna, Thunnus orientalis; Atlantic bluefin tuna, Thunnus thynnus; and southern bluefin tuna, Thunnus maccoyii. Pacific bluefin tuna, T. orientalis, is the largest fish in Scombridae, and the maximum length and weight recorded in the Pacific Ocean are about $300 \mathrm{~cm}$ and $555 \mathrm{~kg}$, respectively. According to the experiment by Shimose et al. (2009), the high growth rate of $T$. orientalis during the first 5 years allows them to attain the body length around $150 \mathrm{~cm}$, and the rate gradually decreases thereafter. However, the growth, in general, stops at the age of ten, and the longevity exceeds 20 years. The size of a male $T$. orientalis is larger than that of a female in the older age groups, and this is

\footnotetext{
* Correspondence: k.sungillee@gmail.com

${ }^{1}$ National Institute of Fisheries Science, Busan 46083, Republic of Korea Full list of author information is available at the end of the article
}

caused by the differential growth rates between the sexes. Harada (1980) stated that spawning of T. orientalis occurs at the age of about 5 years when it reaches around $150 \mathrm{~cm}$ in FL and $60 \mathrm{~kg}$ in weight. Two main spawning grounds of $T$. orientalis had been identified to be in the southwestern North Pacific, one off east Taiwan and one in the south of the East Sea (Okiyama 1974; Chen et al. 2006; Tanaka et al. 2007), but currently, there is no evidence for any local stocks in both spawning regions (Shimose et al. 2009). T. orientalis is a highly migratory species occurring throughout the North Pacific Ocean ranging from the East Asian coast to the western coast of North America and is also recorded as a visitor to the South Pacific (Collette 1999; IUCN 2014). The fish maintains higher body temperatures than ambient temperatures; therefore, this ability would enable them to be distributed widely in the ocean (Carey and Teal 1969; Graham and Dickson 2004). T. orientalis often repeats 


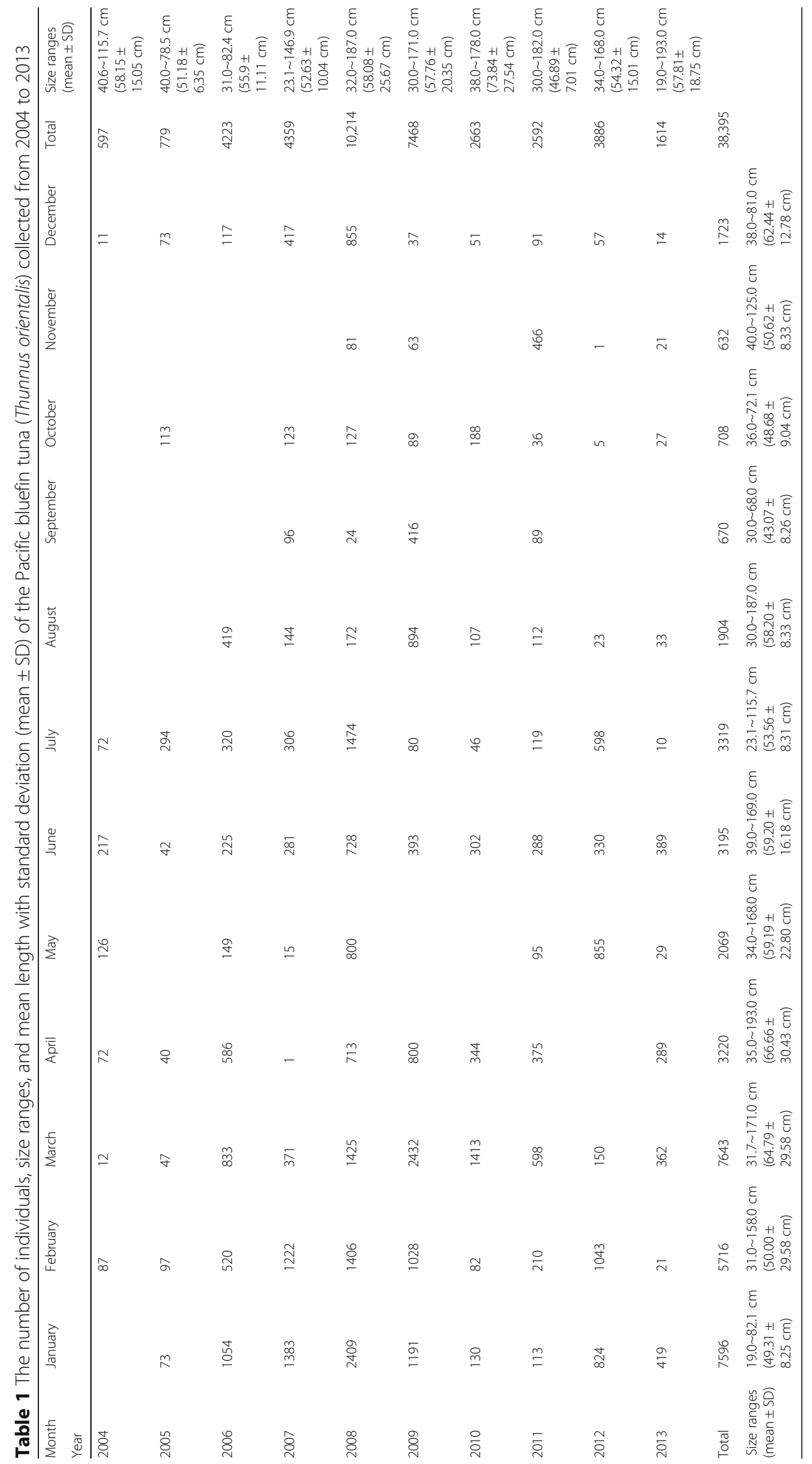


vertical movements below the thermocline in the daytime, although the fish spends most of the time swimming within the surface mixed layer (Kitagawa et al. 2007).

Also, this species feeds on round herring, pompano, mackerel, saury, skipjack tuna, and sardine (Kida 1936; Doi 1960; Yokota et al. 1961). T. orientalis competes with albacore, yellowtail, barracuda, and mackerel over food (Bell 1963). Yokota et al. (1961) mentioned the presence of juvenile $T$. orientalis in the stomachs of skipjack. Yamanaka (1963) stated that the immature has many predators such as seal, dolphin, spear-fish, swordfish, and shark.

The catch of T. orientalis in the Pacific Ocean as well as the world is much less than that of skipjack, yellowfin, and albacore tuna (FAO 2010). Nevertheless, the commercial value of this species exceeds that of other tunas (The Pew Charitable Trusts 2016). The catch of T. orientalis of the Korean fisheries fluctuated annually, which had been at a very low level until the end of the 1990s but increased thereafter. In the case of the North Pacific, it showed the similar trend with the total catch of Korean waters.

Recently, the climate has been changed rapidly, and ocean ecosystems also respond to this change (Hollowed et al. 2011). Many scientists have carried out research about the relationship between climate change and fishery because climate change such as global warming and ocean acidification became a serious issue in the ocean ecosystems. The variation in temperature, wind field, and precipitation has an influence on the ocean's water properties, which sequentially impacts on ocean ecosystem including fish stocks (Drinkwater 2005). Lehodey et al. (2003) stated that the recruitment of tuna species in the Pacific was correlated with the climate indices such as Southern Oscillation Index (SOI) and Pacific Decadal Oscillation Index (PDOI).

Few studies on the fishery and ecological characteristics of T. orientalis in Korean waters have been conducted, although $T$. orientalis was recognized as a commercially important species. For the sustainable yield of $T$. orientalis with the proper stock assessment and management, the ecological research on the distribution of fishing ground and basic biological characteristics should be conducted. Therefore, the aim of this study is to investigate the fishing grounds of $T$. orientalis around Jeju Island of Korea to identify the relationship between the fishing characteristics of $T$. orientalis and environmental factors.

\section{Methods}

In this study, $T$. orientalis fishery-related parameters were collected from the Korean large purse seine fisheries around Jeju Island. The catch and effort (the number of sets) data used in the study area were obtained from Busan Cooperative Fish Market (BCFM) and fisheries cooperatives radio station during 2004-2013. Catch per unit effort

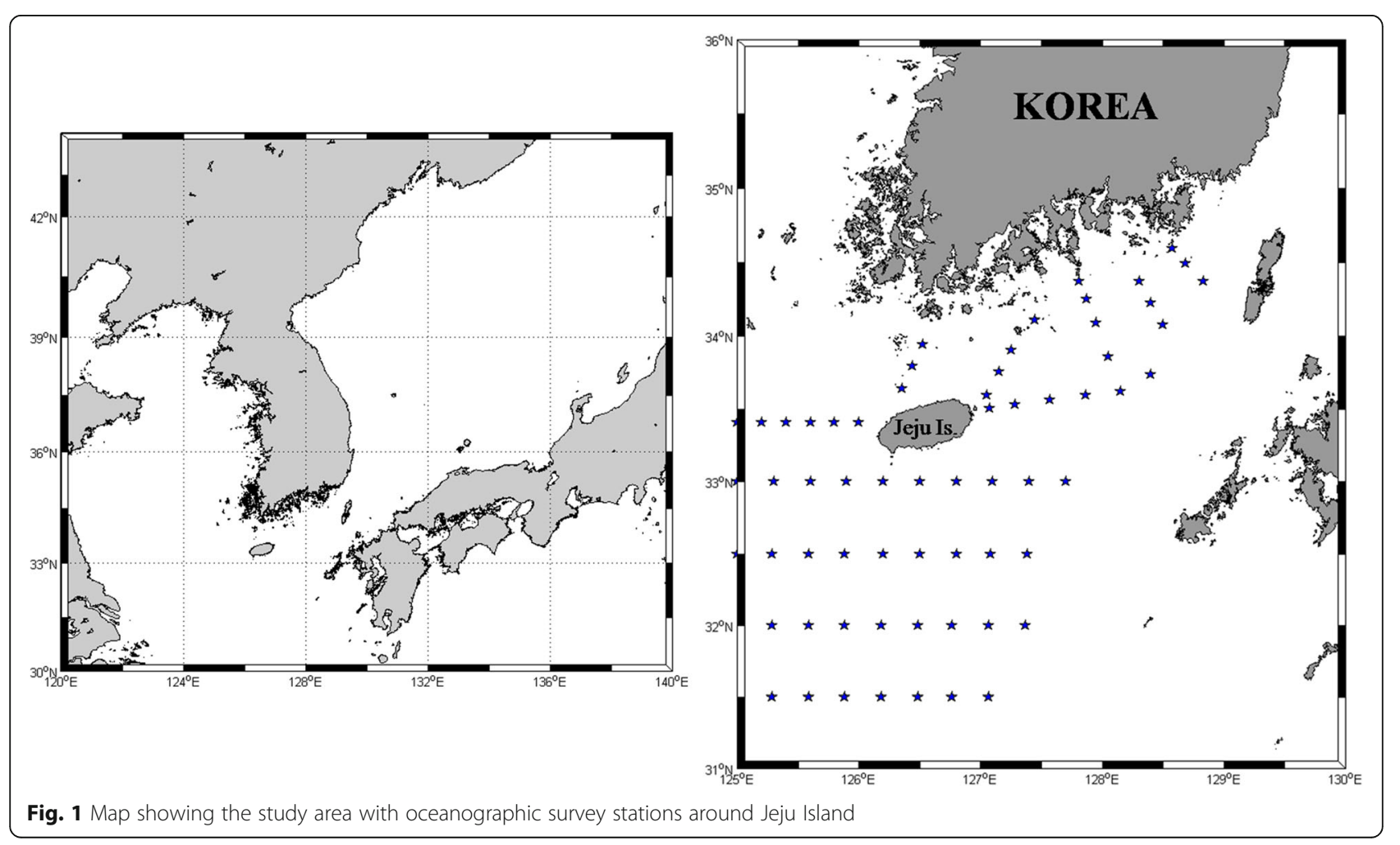


(CPUE) of T. orientalis was calculated based on the catch divided by the number of sets. Fork length (FL) of $T$. orientalis was measured from about 38,000 by the field survey in BCFM during 2004-2013(Table 1). The annual catch data from 2010 to 2013 in Korean waters came from Korean Statistical Information Service (KOSIS, http://kosis.kr/sta tisticsList/statisticsList_01List.jsp?vwcd=MT_ZTITLE\&parentId=F\#SubCont), and the data before 2009 was revised value by calculating the actual weight of $T$. orientalis per box. And those in the North Pacific were obtained from the International Scientific Committee for Tuna and Tuna-like Species in the North Pacific Ocean (ISC, http://isc.fra.go.jp/working_groups/pacific_bluefin_tuna.html) during 1982-2012 to figure out the trends of the annual catch.

The habitat conditions such as seawater temperature, salinity, and dissolved oxygen were examined by bi-monthly information collected through oceanographic surveys (Fig. 1). This oceanographic data from 2004 to 2013 were obtained from the Korea Oceanographic Data Center (KODC). We assumed that seawater properties at the surface and $50 \mathrm{~m}$ off Jeju Island represent the habitat characteristics of $T$. orientalis because $T$. orientalis spend most

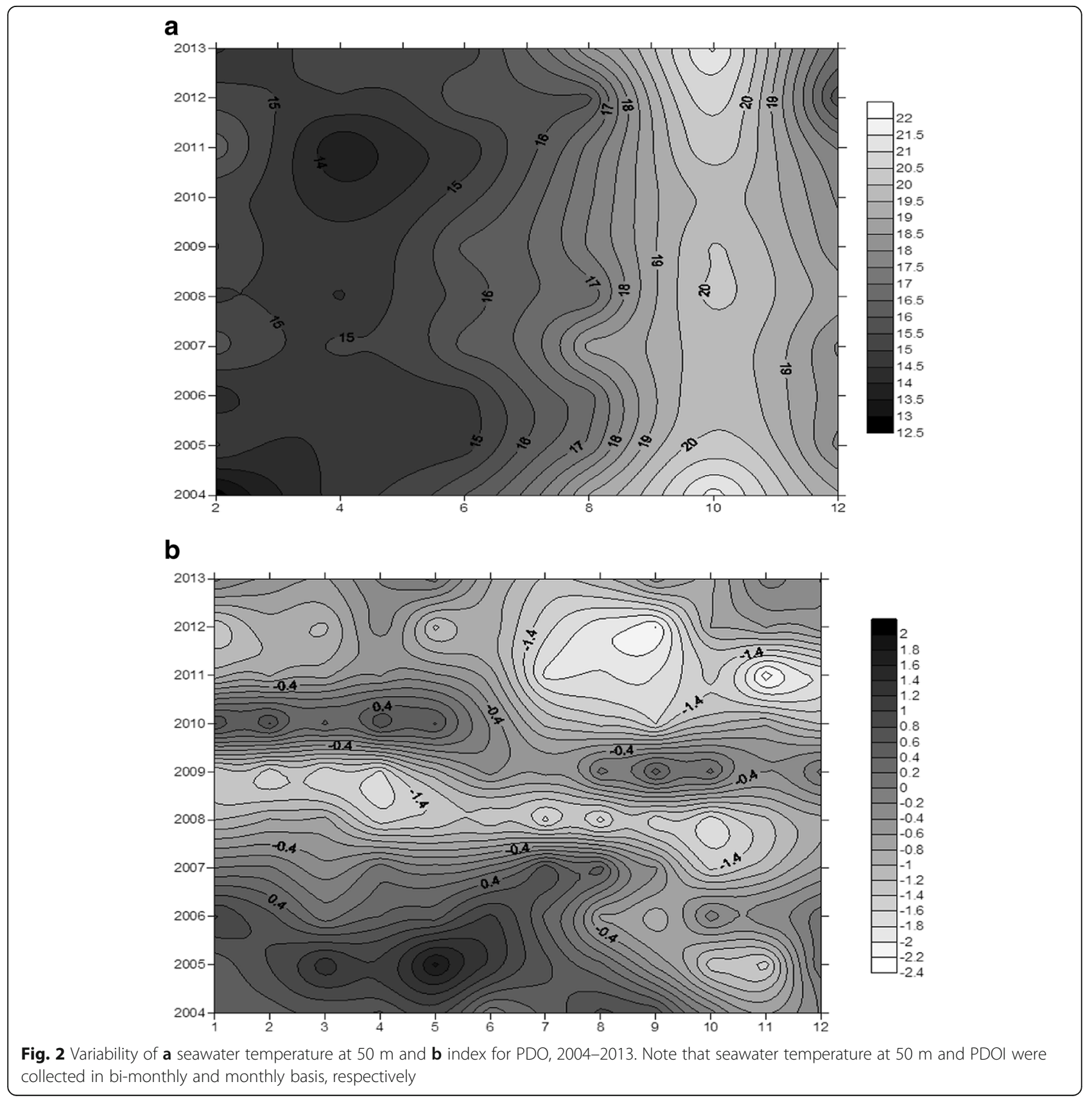


of the time in the mixed layer with the exception of frequent dives (Kitagawa et al. 2000). Annual sea surface temperature (SST) collected by Moderate Resolution Imaging Spectroradiometer (MODIS) satellite during 2004-2013 was investigated to identify the seawater temperature at the fishing ground. In addition to seawater properties, several monthly climate indices such as Pacific Decadal Oscillation Index (PDOI) and the Arctic Oscillation Index (AOI) were selected to correlate with month average of catch and FL of $T$. orientalis using SPSS software. PDOI is the leading empirical orthogonal function (EOF) of monthly sea surface temperature anomalies over the North Pacific (poleward of $20^{\circ} \mathrm{N}$ ) after the global average sea surface temperature has been removed (Deser et al. 2010). And AOI is a low-frequency mode of atmospheric variability of the southern hemisphere. It is defined as a belt of westerly winds or low pressure surrounding Antarctica which moves north or south as its mode of variability (Australian Bureau of
Meteorology 2013). Those climatic indices were collected from http://jisao.washington.edu/pdo/PDO.latest and http://jisao.washington.edu/ao/\#data, respectively.

The joint confident region on the fishing spot of $T$. orientalis (long., lat.) was analyzed to determine the distribution area of $T$. orientalis in the study area (Yang et al. 2012). Joint confident region indicates the ellipse which has the major axis $\left(\lambda_{1}\right)$ and the minor axis $\left(\lambda_{2}\right)$. The formula for calculating the ellipse is as in the following:

$$
\begin{aligned}
& \lambda_{1}=0.5 \cdot\left[S_{1}{ }^{2}+S_{2}{ }^{2}+\sqrt{\left(s_{1}{ }^{2}+s_{2}{ }^{2}\right)^{2}-4\left({s_{1}}^{2}{s_{2}}^{2}-s_{12}{ }^{2}\right)}\right] \\
& \lambda_{2}=s_{1}{ }^{2}+s_{2}{ }^{2}-\lambda_{1}
\end{aligned}
$$

where $s_{1}$ and $s_{2}$ are the standard deviation of $\mathrm{X}$ and $\mathrm{Y}$, and $s_{12}$ is the covariance. Formula 2 is to analyze the
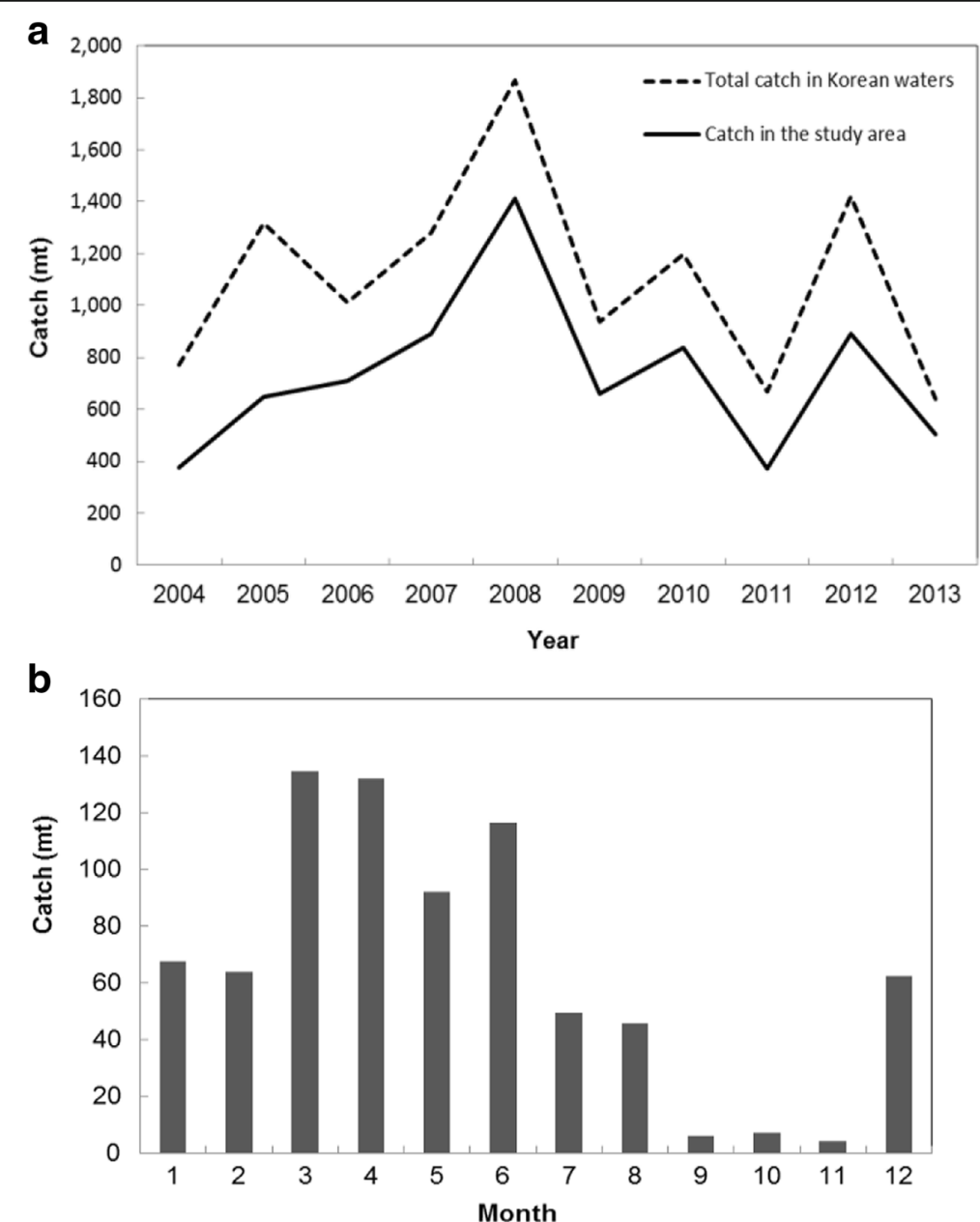

Fig. 3 Changes in a annual catch of T. orientalis caught in Korean waters and in the study area, 2004-2013, and $\mathbf{b}$ monthly mean catch with standard deviation in the study area, 2004-2013 
slopes of the major axis $\left(b_{1}\right)$ and the minor axis $\left(b_{2}\right)$ which indicate the direction of the ellipse.

$$
b_{1}=\frac{s_{12}}{\lambda_{1}-s_{1}^{2}}, b_{2}=\frac{-1}{b_{1}}
$$

\section{Results}

Mean seawater temperature at $50 \mathrm{~m}$ was low in the first half of the year but increased in the second half of the year (Fig. 2a). The catch and the FL of $T$. orientalis in the first half of the year (i.e., winter and spring) were higher than those in the second half (i.e., summer and fall) (Figs. $3 \mathrm{~b}$ and $4 \mathrm{~b}$ ). The time series of annual seawater temperature indicated that year 2007 was relatively the warm period, whereas year 2011 was relatively the cool period (Fig. 2a). The catch of T. orientalis in 2007 was double than those in 2011 (Fig. 3a). Also, the PDOI was generally high from winter through spring and comparatively low from summer through fall (Fig. 2b). In the case of annual PDOI, when the PDOI had a low value such as in 2008, the catch of T. orientalis was high. From 2004 to 2005, however, when the PDOI had a relatively high value, the catch was low (Fig. 3a).

The annual catch of $T$. orientalis in the North Pacific Ocean had continuously fluctuated during 1982-2012 (Fig. 5a). It demonstrated the low catch (about 10,000 t) in the late 1980s through the early 1990s, and a relatively high level of catch (about 20,000 t) maintained from the mid-1990s to the mid-2000s. The annual catch of $T$. orientalis reached the highest $(33,000 \mathrm{t})$ in 2000 and showed a general tendency of decrease thereafter. In Korean waters, the annual catch of $T$. orientalis started $31 \mathrm{t}$ in 1982, and it showed less than $1000 \mathrm{t}$ until the end of the 1990s (Fig. 5b). The catch recorded $2400 \mathrm{t}$ in 2000 , and it hit the record $(2600 \mathrm{t})$ in 2003 . The catch has generally decreased since 2003 with a minor fluctuating pattern. The annual catch trends of $T$. orientalis

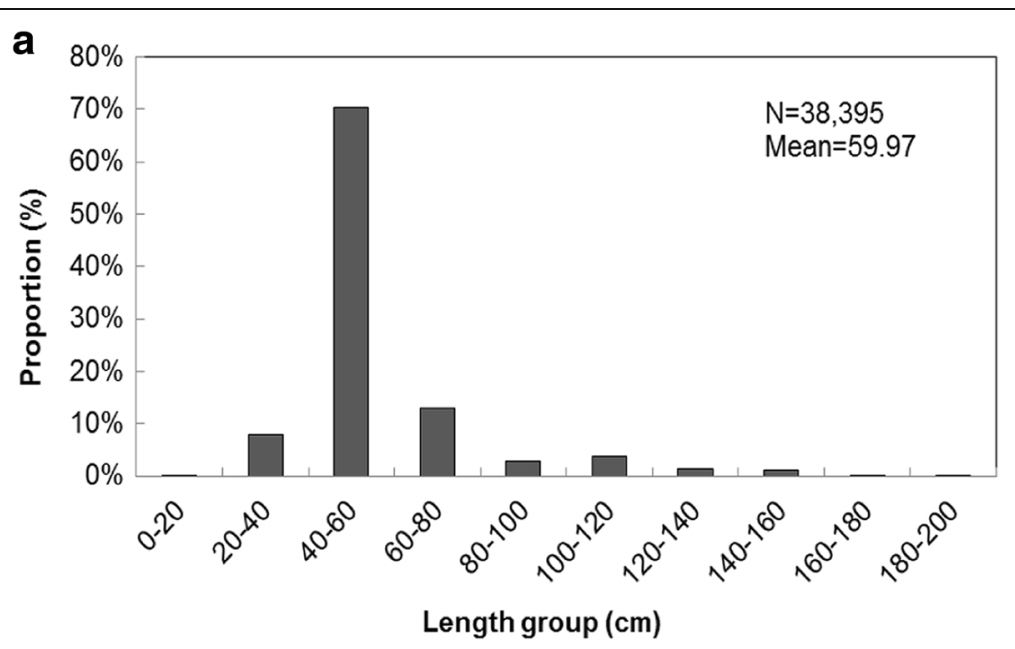

b

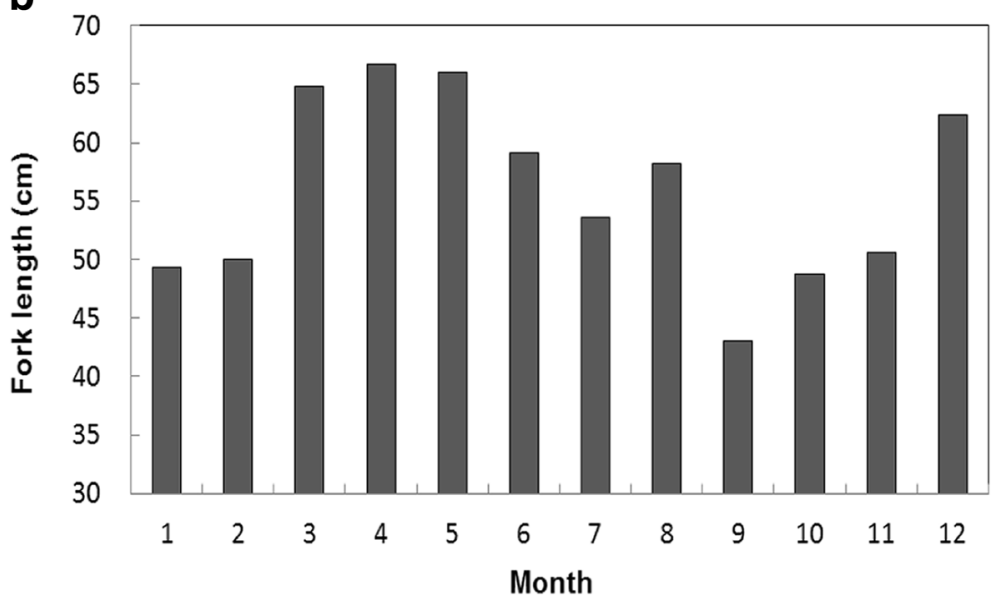

Fig. 4 Length frequency distributions of T. orientalis caught in Korean waters, 2004-2013. a Proportion at each size range. b Monthly mean fork length with standard deviation 


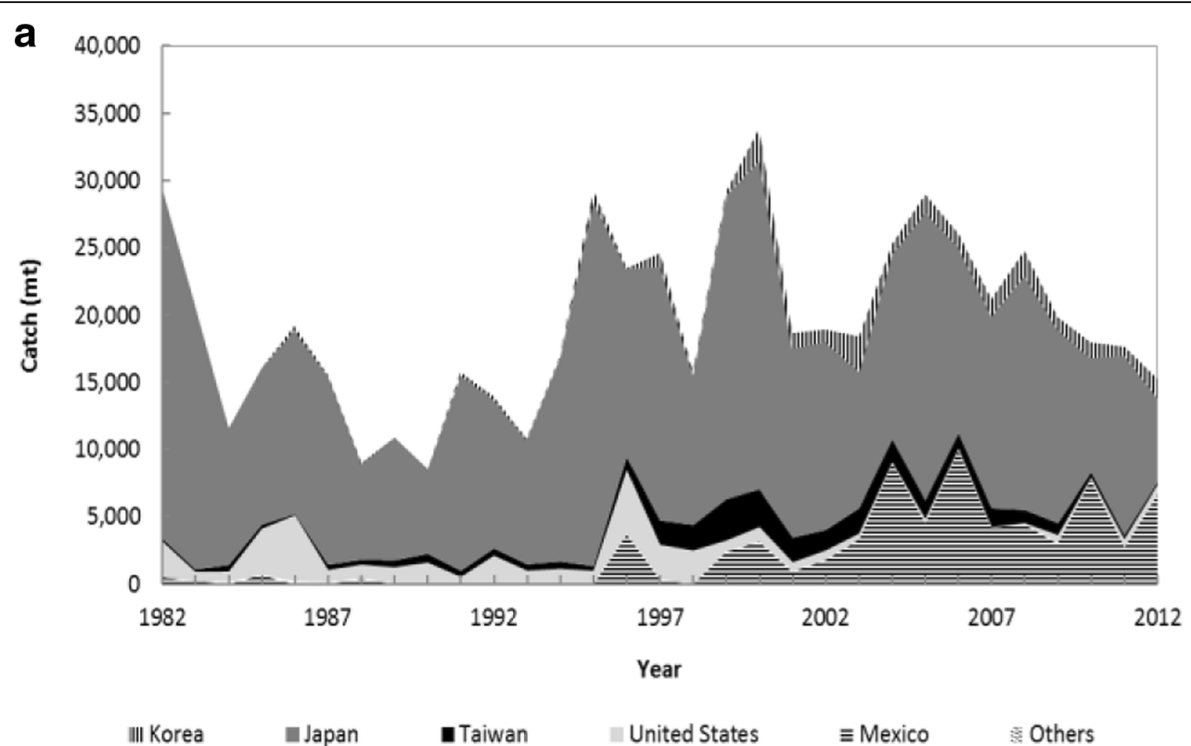

b

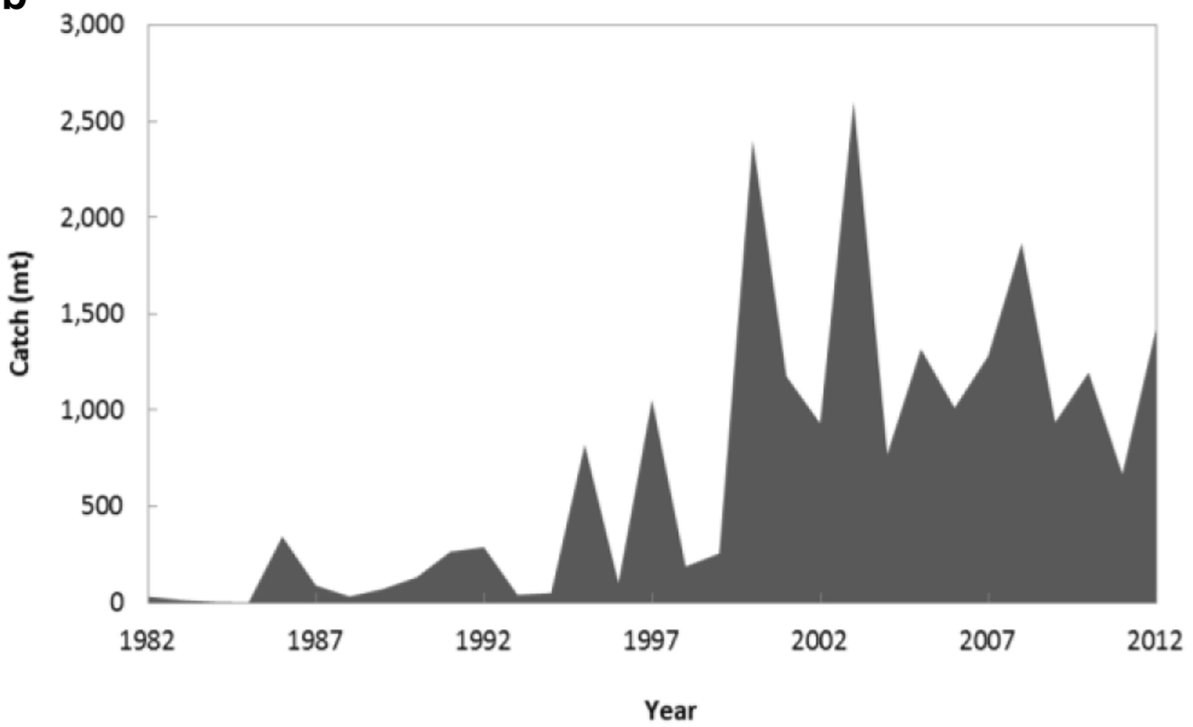

Fig. 5 Annual catch of T. orientalis a in the North Pacific (ISC, http://isc.ac.affrc.go.jp/working_groups/pacific_bluefin_tuna.html), 1982-2012, and b in Korean waters (KOSIS, http://kosis.kr/statisticsList/statisticsList_01List.jsp?vwcd=MT_ZTITLE\&parentld=F\#SubCont), 1982-2012

from the Korean waters, and the study area seemed to be parallel during 2004-2013 (Fig. 3a). It had increased continuously from $350 \mathrm{t}$ in 2004 to $1414 \mathrm{t}$ in 2008 and then tended to decrease reaching $500 \mathrm{t}$ in 2013. Monthly variation of $T$. orientalis indicated that high catches were recorded in spring to early summer while very low catches in fall (Fig. 3b). The catch in March through June occupied about $60 \%$ of the total, and the mean catch in March was the highest (135 t) and continuously decreased to fall. Catches in September to November were only about $2 \%$ of the total catch.

$T$. orientalis caught from the study area during the 2004-2013 period showed the FL range of $19-293 \mathrm{~cm}$ with the mean of about $60 \mathrm{~cm}$ (Fig. 4a). Length frequency graph revealed that the length mode of 40 $60 \mathrm{~cm}$ accounted for $70 \%$ of the total. The second and third largest ones in proportion were the length groups of $60-80 \mathrm{~cm}(13 \%)$ and $20-40 \mathrm{~cm}(8 \%)$, respectively. Monthly mean length of $T$. orientalis indicated that the larger sizes were found in spring (i.e., $66.7 \mathrm{~cm}$ in April) (Fig. 4b). In general, smaller sizes appeared in fall (i.e., $43 \mathrm{~cm}$ in September).

The range and direction of the joint confident region (i.e., ellipse) were analyzed in every year based on catch information, and the locations of ellipse were overlapped to the SST distribution in the study area (Fig. 6). Most ellipses located on the east side of Jeju Island and the major axis of ellipses seemed to parallel (i.e., east-west 

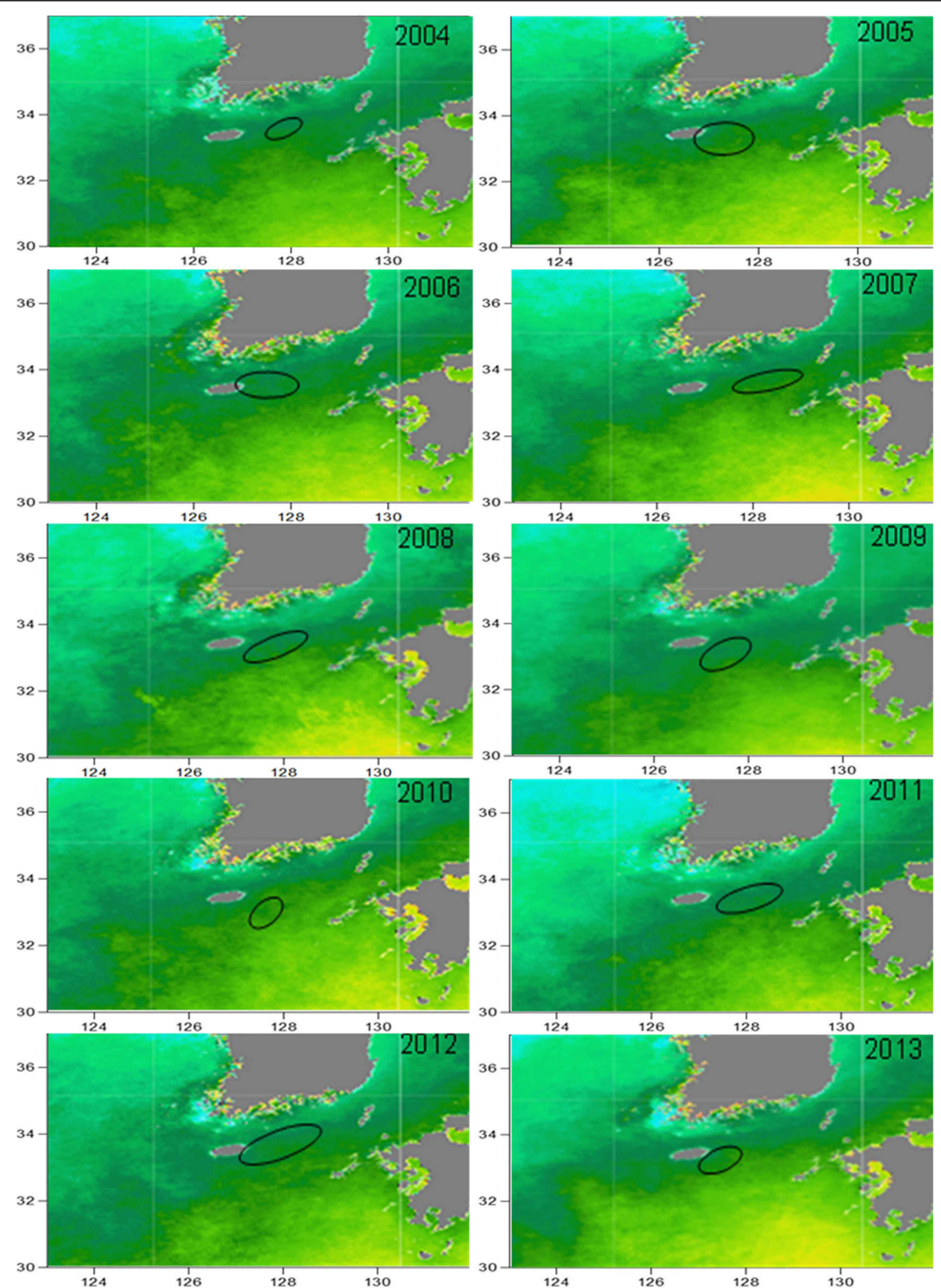

Sea Surface Temperature $\left({ }^{\circ} \mathrm{C}\right)$

\section{$\begin{array}{lllllllllllll}10 & 12 & 14 & 16 & 18 & 20 & 22 & 24 & 26 & 28 & 30\end{array}$}

Fig. 6 Comparison between the joint confident regions in the fishing grounds of T. orientalis and the annual mean SST, 2004-2013 
direction) to the flow direction of Tsushima Current. Distribution of fishing ground matched with the specific annual temperature ranges observed by MODIS satellite. For example, in 2004, the main fishing ground of T. orientalis was distributed over the SST range of $19-20{ }^{\circ} \mathrm{C}$, and temperature information in other years also showed the similar ranges. In general, the locations of main fishing areas seemed to be in SST ranges of $19-23{ }^{\circ} \mathrm{C}$ off Jeju Island during 2004-2013.

The environmental, fisheries, and biological data were statistically examined using correlation analysis (Table 2). Since the PDOI, catch, and FL showed higher values in the first half than the second half of the year (Figs. 2b, $3 \mathrm{~b}$, and $4 \mathrm{~b}$ ), while seawater temperature at $50 \mathrm{~m}$ revealed the opposite pattern (Fig. 2a); the PDOI has significant positive correlations with monthly mean catch $(r=0.856, p<0.01)$. Seawater temperature at $50 \mathrm{~m}$ showed negative correlations with monthly mean catch $(r=-0.755$, $p<0.01)$ and monthly mean FL $(r=-0.592, p<0.01$ for $)$. The lower the temperature at $50 \mathrm{~m}$ in depth was, the higher the catch and the bigger the length of $T$. orientalis became. On the other hand, there were no significant correlations between catch and length with environmental factors such as salinity, dissolved oxygen, and AOI.

Spatial distribution of CPUE of T. orientalis overlapped with the mean temperature at $50 \mathrm{~m}$ during the period of 2004 to 2013 (Fig. 7). In February, the mean temperature at $50 \mathrm{~m}$ of the study area was about $15.5^{\circ} \mathrm{C}$, and CPUE was lower than the other season and had high value (1-2 t/set) near $16{ }^{\circ} \mathrm{C}$ isotherm. In April, the mean temperature at $50 \mathrm{~m}$ was similar to February, but CPUE was found to be over $10 \mathrm{t} / \mathrm{set}$ in the $15{ }^{\circ} \mathrm{C}$ isotherm. In June, the mean temperature at $50 \mathrm{~m}$ was about $16{ }^{\circ} \mathrm{C}$, and CPUE was high (1-7 t/set) in the temperature of $15-16^{\circ} \mathrm{C}$. Seawater temperatures were increased until August, and the CPUE also maintained in high levels (1-11 t/set). However, in October,

Table 2 Correlation coefficients between catch and length of Pacific bluefin tuna, Thunnus orientalis, with environmental factors off the Jeju Island during 2004-2013

\begin{tabular}{lll}
\hline Environmental factors & $\begin{array}{l}\text { Monthly } \\
\text { mean catch }\end{array}$ & $\begin{array}{l}\text { Monthly } \\
\text { mean length }\end{array}$ \\
\hline PDOI & $0.856^{* *}$ & - \\
AOI & 0.312 & - \\
Seawater temperature at $0 \mathrm{~m}$ & -0.359 & -0.408 \\
Seawater temperature at $50 \mathrm{~m}$ & $-0.755^{* *}$ & $-0.592^{* *}$ \\
Salinity at $0 \mathrm{~m}$ & 0.048 & 0.194 \\
Salinity at $50 \mathrm{~m}$ & 0.409 & 0.443 \\
Dissolved oxygen at $0 \mathrm{~m}$ & 0.570 & 0.314 \\
Dissolved oxygen at $50 \mathrm{~m}$ & 0.500 & 0.325
\end{tabular}

The numbers used for the climate indices (i.e., PDOI and AOI) and the seawater properties (temperature, salinity, and dissolved oxygen) were 12 (monthly) and 6 (bi-monthly), respectively

***ndicates the significant level of 0.01 the mean seawater temperature at $50 \mathrm{~m}$ marked the highest (about $21{ }^{\circ} \mathrm{C}$ ), and CPUE sharply dropped below $1 \mathrm{t} /$ set. In December, seawater temperature was decreased to about $19^{\circ} \mathrm{C}$, and CPUE was again increased to $18.8 \mathrm{t} / \mathrm{set}$.

\section{Discussion}

The annual total catch of $T$. orientalis had fluctuated in Korean waters from 2004 to 2013. The catch of $T$. orientalis in the study area had occupied about 50 $80 \%$ of the total catch. Also, this study area is regarded as the main fishing ground of $T$. orientalis in Korean waters. Therefore, we assumed that the fishery and ecological characteristics of $T$. orientalis caught in the study area could represent those of $T$. orientalis lived in Korean waters. We analyzed how variations in environmental factors and climate indices in the study area have effects on the catch and the length of $T$. orientalis. The monthly mean catch and length of $T$. orientalis in this study showed a strong seasonal difference, and most of $T$. orientalis caught around Jeju Island ranged $40-60 \mathrm{~cm}$ that was classified as an immature (Yukinawa 1967). On the other hand, the fishing ground of $T$. orientalis was located off the eastern Jeju Island, and the annual mean SST ranged $19-23{ }^{\circ} \mathrm{C}$. According to Fig. 8, T. orientalis has two spawning grounds that are located in the northern area of Kuroshio axis in the Taiwan Sea and the East Sea (Bayliff 1994; Okiyama 1974; Chen et al. 2006; Tanaka et al. 2007). Therefore, the fishing ground around Jeju Island is regarded as the path for migrating northward of immature T. orientalis which was spawned in the Taiwan Sea.

The analysis between the temperature at $50 \mathrm{~m}$ and the monthly mean catch of $T$. orientalis showed that the lower the seawater temperature was, the higher the catch was available. The temperatures in April and June indicated the high catch in $15-16{ }^{\circ} \mathrm{C}$ ranges, which were a relatively cool condition, whereas the temperatures in October and December were high (about $20{ }^{\circ} \mathrm{C}$ ), but catches were low. Schick et al. (2004) inferred that the change of the seawater temperature affecting tuna species was very important. Bayliff (1994) insisted that a temperature range for optimum activity of $T$. orientalis was $14-18{ }^{\circ} \mathrm{C}$. These results from previous studies are similar to our results representing high catch in the temperature range of $15-16^{\circ} \mathrm{C}$. In the case of CPUE, the mean temperature of areas with high CPUE was also at about $15-16{ }^{\circ} \mathrm{C}$. And in addition, a temperature front (i.e., by colliding two water masses, where the temperature rapidly changed rather than others) could be regarded as another factor affecting the high CPUE in August. Generally, marine populations, not only prey but also predator, were abundant in frontal areas due to the concentrated nutrients. In the previous study, the catch of skipjack and 

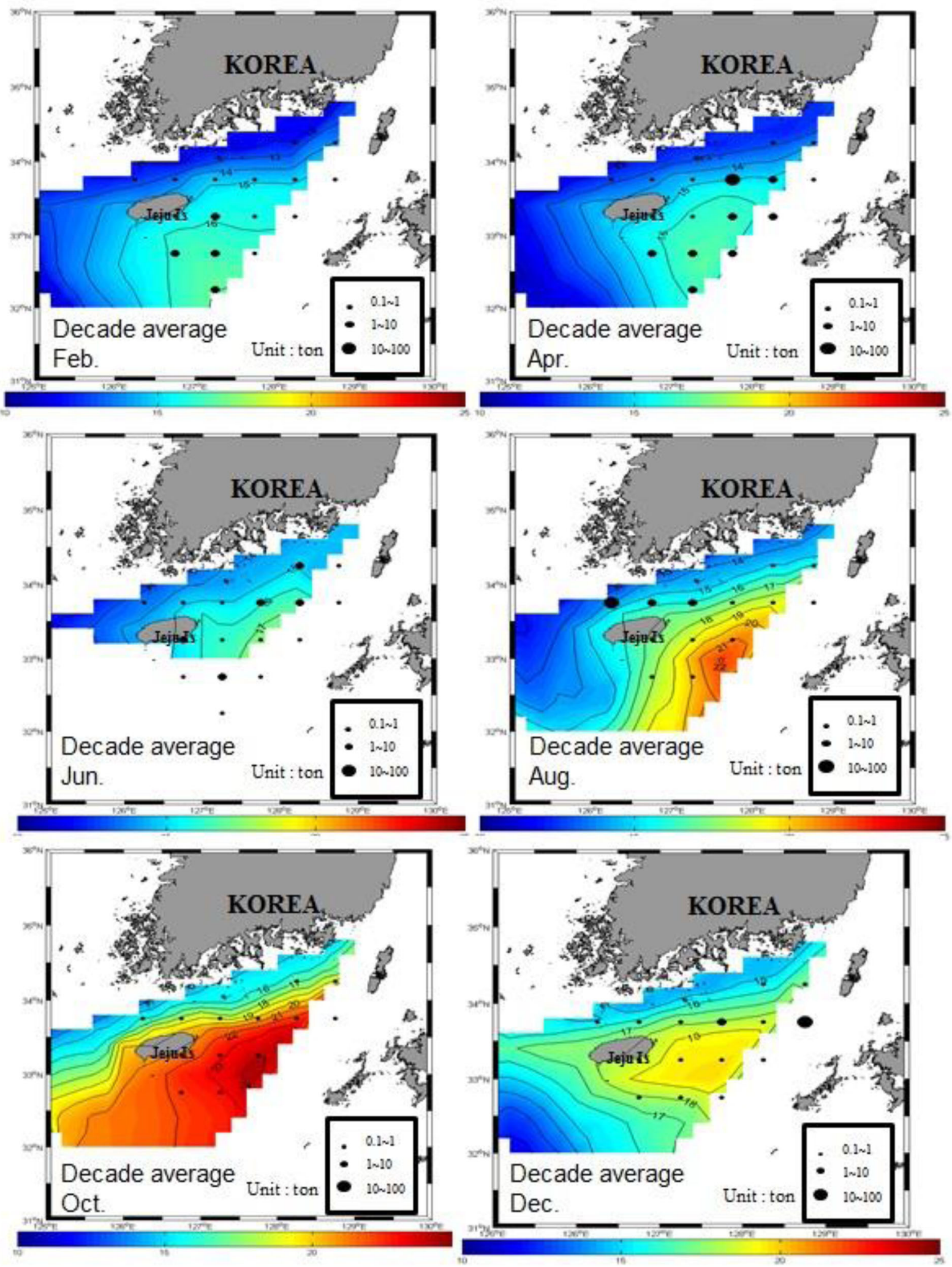

Fig. 7 Spatial distribution of CPUE of T. orientalis off the southern coast of Korean Peninsula over the mean temperature distribution at $50 \mathrm{~m}$ during 2004 to 2013 


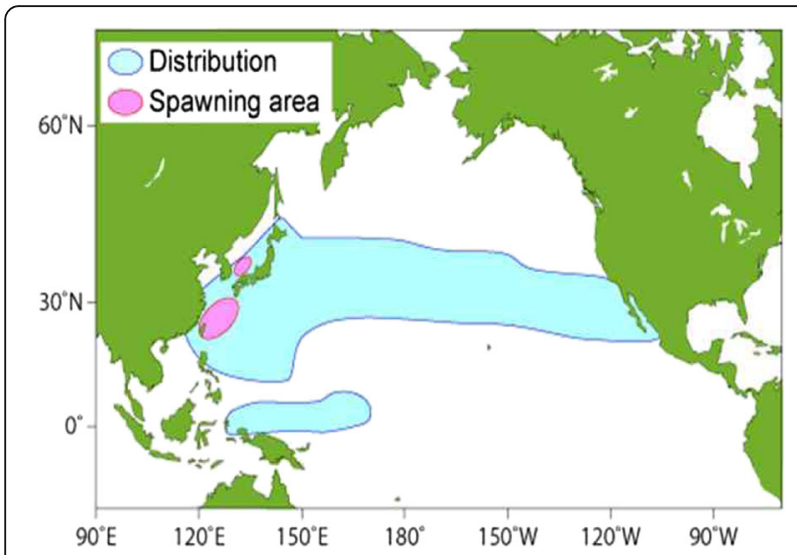

Fig. 8 Distribution and spawning areas of Pacific bluefin tuna, Thunnus orientalis

(ISC, http://isc.fra.go.jp/working_groups/pacific_bluefin_tuna.html)

albacore recorded high catches in the frontal area which was related to the temperature gradient and chlorophyll concentration (Laurs et al. 1984; Fiedler and Bernard 1987). Also, Podesta et al. (1993) mentioned that the catch of swordfish was high in SST frontal area. Likewise, the research for other factors such as prey affecting the high CPUE and the catch is necessary. We, however, had difficulty in comparing the relationship between CPUE as well as the catch and the temperature in the whole area or this study area, because the area in which the temperature was observed did not cover the entire area of catch.

According to the result of correlation coefficient analysis between the monthly average of PDOI and the catch, when PDOI had the highest value, the value of the catch was also high. This result meant that SST was low if PDOI indicated a high value. Therefore, the high PDOI resulted in the increasing of $T$. orientalis catch. In the previous study, the catch of chum salmon caught in the North Pacific Ocean was significantly correlated with the climate indices including PDOI (Kim et al. 2007). In the analysis between the monthly mean length and seawater temperature at $50 \mathrm{~m}$, the higher the temperature was, the smaller the length of $T$. orientalis became. This result is inferred that small one pretends the warm condition, comparatively. According to Brill and Lutcavage (2001), juvenile of Atlantic bluefin tuna appear to have a clear preference for warm condition in the range of $22-25{ }^{\circ} \mathrm{C}$. In this study, when the temperature was the highest about $21{ }^{\circ} \mathrm{C}$ in October, the length of $T$. orientalis was the smallest. On the other hand, SST was not significantly correlated with the catch and the length. However, according to this analysis, the SST pattern of the entire scale throughout North Pacific Ocean (PDOI) has a significant correlation with the catch. More research is needed to answer this question.

\section{Conclusions}

In the relationship between the monthly catch and environmental factors, the catch of $T$. orientalis was affected by seasonal variation. When the seawater temperature at $50 \mathrm{~m}$ was low (i.e., winter and spring), the catch was high. In the case of the PDOI, when the PDOI was high (i.e., winter and spring), the catch was high. In the time series of annual variation, when the SST was comparatively warm (i.e., warm period), the catch of $T$. orientalis was high. In addition, when the PDOI had low values, the catch was high. The fishing ground had been formed in the east of Jeju Island in the period of this study. The highest catch and catch per unit effort (CPUE) of $T$. orientalis around Jeju Island occurred either when the seawater temperature at $50 \mathrm{~m}$ ranged between 15 and $16{ }^{\circ} \mathrm{C}$ or when the catch was taken near the frontal area.

\section{Abbreviations \\ AOI: Artic Oscillation Index; BCFM: Busan Cooperative Fish Market; CPUE: Catch per unit effort; FL: Fork length; ISC: International Scientific Committee for Tuna and Tuna-like Species in the North Pacific Ocean; KODC: Korea Oceanographic Data Center; KOSIS: Korean Statistical Information Service; PDOI: Pacific Decadal Oscillation Index; SOl: Southern Oscillation Index; SST: Sea surface temperature}

\section{Acknowledgements}

The authors thank all the people who helped publish this paper. This study was supported by a grant from the National Institute of Fisheries Science (R2017027)

\section{Funding}

This study was supported by a grant from the National Institute of Fisheries Science (R2017027).

\section{Availability of data and materials}

All except for datasets from other countries within this study are available from the corresponding author on reasonable request.

\section{Authors' contributions}

All authors designed the direction of this study. They read and approved the manuscript.

\section{Ethics approval}

The experiment with the animals was conducted by the guidelines of National Institute of Fisheries Science.

\section{Consent for publication}

Not applicable.

\section{Competing interests}

The authors declare that they have no competing interests.

\section{Publisher's Note}

Springer Nature remains neutral with regard to jurisdictional claims in published maps and institutional affiliations.

\section{Author details}

${ }^{1}$ National Institute of Fisheries Science, Busan 46083, Republic of Korea.

${ }^{2}$ Pukyong National University, Busan 48513, Republic of Korea. 
Received: 20 September 2017 Accepted: 13 December 2017 Published online: 08 January 2018

\section{References}

Australian Bureau of Meteorology. 2013. The southern annular mode. Retrived from http://www.bom.gov.au/climate/enso/history/ln-2010-12/SAM-what.shtml. Accessed 15 Sept.

Bayliff WH. A review of the biology and fisheries for northen bluefin tuna, Thynnus thynnus, in the Pacific Ocean. FAO Fish Tech Pap. 1994;336:244-95.

Bell RR. Synopsis of biological date on California bluefin tuna Thynnus saliens Jordan and Evermann 1926. FAO Fish Rep. 1963;6(2):308-421.

Brill RW, Lutcavage ME. Understanding environmental influences on movements and depth distributions of tunas and billfishes can significantly improve population assessments. In: American Fisheries Society Symposium. American Fisheries Society. 2001. p. 179-198.

Carey FG, Teal JM. Regulation of body temperature by the bluefin tuna. Comp Biochem Physiol. 1969;28(1):205-13.

Chen KS, Crone P, Hsu CC. Reproductive biology of female Pacific bluefin tuna Thynnus orientalis from south-western North Pacific Ocean. Fish Sci. 2006; 72(5):985-94.

Collette BB. Mackerels, molecules, and morphology. In: Proceedings of the 5th Indo-Pacific Fish Conference. Seret B and Sire JY, eds. Societe Francaise d'Ichtyologie, Paris, 1999;149-164.

Deser C, Alexander MA, Xie SP, Phillips AS. Sea surface temperature variability: patterns and mechanisms. Annu Rev Mar Sci. 2010;2:115-43.

Doi T. On the predatory relationships among bluefin tuna and coastal fishes in the southern waters of Japan. Bull Japan Soc Sci Fish. 1960;26(2):99-102.

Drinkwater KF. The response of Atlantic cod (Gadus morhua) to future climate change. ICES J Mar Sci. 2005;62(7):1327-37.

FAO. Global Tuna Catches by Stock. 2010 Retrieved from http://www.fao.org/ fishery/statistics/tuna-catches/en

Fiedler PC, Bernard HJ. Tuna aggregation and feeding near fronts observed in satellite imagery. Cont Shelf Res. 1987;7(8):871-81.

Graham JB, Dickson K. Tuna comparative physiology. J Exp Biol. 2004;207(23): 4015-24.

Harada T. Development and future outlook of studies on the aquaculture of tunas In: Maguro Gyogyo Kyogikai Gijiroku, Suisancho-Enyo Suisan Kenkyusho (Proceedings of the Tuna Fishery Research Conference). Japan Fisheries Agency-Far Seas Fisheries Research Laboratory, Simizu, 1980 6-7.

Hollowed AB, Barange M, Ito S-I, Kim S, Loeng H, Peck MA. Effects of climate change on fish and fisheries: forecasting impacts, assessing ecosystem responses, and evaluating management strategies. ICES J Mar Sci. 2011;68(6):984-5.

IUCN. Red list of threatened species. Thunnus orientalis. 2014 Retrieved from http://www.iucnredlist.org/details/summary/170341/0

Kida T. On the surface temperature of water in the tunny fishing grounds off Kusiro and Urakawa in summer. Bull Jap Soc Sci Fish. 1936;5(2):87-90.

Kim S, Kang S, Seo H, Kim E, Kang M. Climate variability and chum salmon production in the North Pacific. The Sea. 2007;12(2):61-72.

Kitagawa T, Boustany AM, Farwell CJ, Williams TD, Castleton MR, Block BA. Horizontal and vertical movements of juvenile bluefin tuna (Thunnus orientalis) in relation to seasons and oceanographic conditions in the eastern Pacific Ocean. Fish Oceanogr. 2007;16(5):409-21.

Kitagawa T, Nakata H, Kimura S, Itoh T, Tsuji S and Nitta A. Effect of ambient temperature on the vertical distribution and movement of Pacific bluefin tuna (Thunnus orientalis). Mar Ecol Prog Series. 2000;206,251-260.

Laurs RM, Fiedler PC, Montgomery DR. Albacore tuna catch distribution relative to environmental features observed from satellites. Deep Sea Res. 1984;31(9): 1085-99.

Lehodey P, Chai F, Hampton J. Modelling climate-related variability of tuna populations from a coupled ocean-biogeochemical-populations dynamics model. Fish Oceanogr. 2003;12(4-5):483-94

Okiyama M. Occurrence of the postlarvae of bluefin tuna, Thynnus thynnus, in the Japan Sea. Bull Japan Sea Reg Fish Res Lab. 1974;25:89-97.

Podesta GP, Browder JA, Hoey JJ. Exploring the association between swordfish catch rates and thermal fronts on U.S. longline grounds in the western North Atlantic. Cont Shelf Res. 1993;13(2-3):253-77.

Schick RS, Goldstein J, and Lutcavage ME. Bluefin tuna (Thunnus Thynnus) distribution in relation to sea surface temperature fronts in the Gulf of Maine (1994-96). Fish Oceanogr. 2004;13(4),225-238.

Shimose T, Tanabe T, Chen KS, Hsu CC. Age determination and growth of Pacific bluefin tuna, Thunnus orientalis, off Japan and Taiwan. Fisf Res. 2009;100(2):134-9.
Tanaka Y, Mohri M, Yamada H. Distribution, growth and hatch date of juvenile Pacific bluefin tuna Thynnus orientalis in the coastal area of the sea of Japan. Fish Sci. 2007;73(3):534-42.

The Pew Charitable Trusts. Netting billions: a global valuation of tuna. 2016 Retrieved from http://www.pewtrusts.org/en/research-and-analysis/reports/ 2016/05/netting-billions-a-global-valuation-of-tuna. Accessed 15 Sept.

Yamanaka H. Synopsis of biological data on kuromaguro Thynnus orientalis (Temminck and Schlegal) 1942 (Pacific Ocean). FAO Fish Rep. 1963;6(2), 180-217.

Yang JH, Lee SI, Yoon SC, Kim JB, Chun YY, Kim SW, Lee JB. Migration and distribution changes of the sandfish, Arcroscopus japonicus in the East Sea. J Korean Soc Fish Tech. 2012;48(4):401-14.

Yokota T, Toriyama M, Kanai F, Nomura S. Studies on the feeding habit of fishes. Rep Nankai Reg Fish Res Lab. 1961;14:1-234.

Yukinawa M. Age and growth of bluefin tuna, Thynnus thynnus (Linnaeus), in The North Pacific Ocean. Rep Nankai Reg fish res lab 25, 1967 1-18.

\section{Submit your next manuscript to BioMed Central and we will help you at every step:}

- We accept pre-submission inquiries

- Our selector tool helps you to find the most relevant journal

- We provide round the clock customer support

- Convenient online submission

- Thorough peer review

- Inclusion in PubMed and all major indexing services

- Maximum visibility for your research

Submit your manuscript at www.biomedcentral.com/submit 